\title{
GOVERNANCE AND TOURISM RESILIENCE DURING THE COVID19 CRISIS. CASE STUDY BUKOVINA, ROMANIA
}

\author{
Daniela MATEI* \\ Gh. Zane Social and Economic Research Institute, Iași, Romanian Academy, România, e-mail: daniela_matei2004@yahoo.com \\ Viorel CHIRIT Ă \\ Ștefan cel Mare University, History and Geography Faculty, Department of Geography, Suceava, România, e-mail: nchirita @ gmail.com
}

\author{
Maria Magdalena LUPCHIAN
}

Ştefan cel Mare University, History and Geography Faculty, Department of Geography, Suceava, România, e-mail: mmlupchian@ gmail.

\begin{abstract}
Citation: Matei, D., Chiriță, V., \& Lupchian, M.M. (2021). GOVERNANCE AND TOURISM RESILIENCE DURING THE COVID19 CRISIS. CASE STUDY BUKOVINA, ROMANIA. GeoJournal of Tourism and Geosites, 34(1), 256-262. https://doi.org/10.30892/gtg.34135-646
\end{abstract}

\begin{abstract}
The COVID-19 outbreak which pushed the public actors to seek out customized solutions adjusted for local development. The present paper investigates the role played by the public administration in rebuilding and supporting the tourist sector in Bukovina which has been severely affected by the restrictions imposed by pandemic. The study used a mixed research method: quantitative analysis (applied questionnaires) and qualitative research (interviews). Although the local administration has a limited jurisdiction of the te rritorial-administrative units, the current sanitary crisis along with the economic one have started to affect territories and populations more and more extended, which pushed the public actors to seek out customized solutions adjusted for local development. The results show that the types of governance applied by the county and local administration will have a decisive impact upon the recovery of the tourism sector.
\end{abstract}

Key words: resilience, governance, local administration, COVID-19, Bukovina, România.

$* \quad * * * * *$

\section{INTRODUCTION}

The sanitary crisis which was triggered by COVID-19 started on the 12th of March 2020 as World Health Organization declared it a pandemic, resulting in a domino effect on the health, economic, and sociocultural systems worldwide. The necessary sanitary measures meant to limit the spread of the virus, such as social distancing, travel restrictions and bans on mobility, isolation and quarantine - either mandatory or self-imposed, have put a stop on tourism and turned the time spent inside, at home, into a real challenge. Even if tourism is largely regarded as a vulnerable activity exposed to a series of risk factors, such as environment, politics, military or sanitary issues (Gössling et al., 2020; Novelli et al., 2018), the current situation is quite different due to the global impact as all the countries in the world, in response to the pandemic, have imposed travel restrictions since April 20. In what concerns the travel destinations, 97 of them (45\%) closed their borders entirely or partially for tourists, 65 destinations (30\%) suspended totally or partially the international flights, while 39 places (18\%) introduced new prohibiting measures for travellers coming from certain countries (UNWTO, 2020). The attempts of giving an accurate forecast of the pandemic's effects on the tourism industry, namely HoReCa, have been swiftly surpassed by the fast pace of the virus spread at global level. Tourism is one of the most affected sectors in both terms of offer and demand. Since it is an interdependent industry, the current circumstances of the global economy threatened by recession, geopolitical tensions, social and commercial pressures and anxieties, as well as the yet uncertain development of the pandemic along with the security measures taken by most countries (restricting travel, closing borders, suspending cultural events, activities of the commercial centers, accommodation units, and restaurants) are further concerns to the tourism business (Muscalu, 2020).

In Romania, the pandemic has impacted heavily on the tourism. For 3 months (March-May 2020), nearly 97\% of the accommodation units were closed, while a small percentage were still in business as they hosted quarantined persons or medical personnel from the front line of COVID-19. From an economic activity that covered almost 3\% of the national GDP to practically zero, that was a harsh shift which completely lacked any transition period. Both the hosting units and tourism agencies registered massive cancellations and decreases in reservations. Since early March 2020, the hotel vacancy rates in Bucharest were by $40 \%$ down and by 50\% down in the case of resorts (INS a, 2020). This was followed by closing over $90 \%$ of the accommodation units, while in April, the National Institute of Statistics estimated a negative conjectural balance of $-99 \%$ for the hosting facilities units, and of $-97 \%$ for the tourism agencies (INS b, 2020).

The present paper is based on the premises that the regional and local impact of COVID-19 crisis has a highly heterogeneous nature with a strong territorial reach and deep implications for the population involved. Under the circumstances, local authorities are the prime responsible players to address such complex and challenging issues, namely isolation measures, health care, social services, supporting small entrepreneurs as well as providing ongoing support for public investments as a key element of resilience and fast recovery. Therefore, an extra responsibility is being placed on the broad shoulders of local administration which needs to apply a multi-level management and address urgent measures, such as free circulation, tourism, and leisure needs along with sanitary status, suspension of numerous jobs or maintaining the major economic branches that support or define the region. The analysis performed has taken the tourist region of Bukovina as area of reference. This region, in terms of accommodation, is the third tourist destination in Romania. The paper aims to identify the point of view shared by the local administration regarding the development trends of the tourism in Bukovina within the current pandemic context, and, also its resilience models. Under the circumstances of a pandemic globally and swiftly spread, the present paper holds two inter-relational objectives: the former addresses the tourist profile of a region with many generous offers such as Bukovina, but deeply affected by the general perception of Suceava County largely regarded these days as an uncertain tourist destination due to the pandemic situation in the region; the latter objective tackles the manner in which was perceived the governance applied by the local authority through concrete actions at a particularly difficult time for the tourism entrepreneurs and operators. Although the subject of research — the relation between the new coronavirus pandemic and tourism - makes

\footnotetext{
* Corresponding author
} 
reference to a fact still ongoing whose consequences cannot be accurately estimated at the time, there are already many studies tackling various approaches of the relation between tourism and pandemic. These studies have either a general nature on analysing possible lines of research in the field (Sigala, 2020), how this pandemic impacted upon the world economy and therefore, upon tourism (Gössling et al., 2020, McKibbin and Fernando, 2020), or they consider the particular features related to the direct relation between pandemic and the collapse of the tourist business at regional and global level. The conclusions of these scientific papers, regardless of the scale, are focused on two main id eas: tourism is one of the most affected sectors by the current crisis; however, and, at the same time, the changes triggered by the pandemic on the matter of tourism demand can become the turning point in the case of this sector, an opportunity for the development of the tourist activities in a different paradigm — travel better not less, experience the other side of common destination etc (Sigala, 2020; Gossling et al., 2020).

Another distinctive group of researches on tourism and COVID-19 are concerned with an unexpected and rather surprising opportunity given to the unsustainable tourism which has reached a global scale in the past years. The present crisis will encourage such practices to shift to a more sustainable model. These studies dispute the mechanisms and systems supporting the type of mobility which gen erated the mass tourism and regards them as an effective tool for transmitting the pandemic (Higgins-Desbiolles, 2020). If we take a closer look, there are studies analysing the manner in which the pandemic has influenced the tourist behaviour towards travel itself and features of the destination (Chebli and Said, 2020; Higgins-Desbiolles, 2020; Wachyuni and Kusumaningrum, 2020, Özdemir and Yildiz, 2020). Here, too, another common idea is outlined: the changes occurred in the tourist behaviour, whether they are connected to the destination, the quality of services or/ and the preferred way of travelling, should be acknowledged by the major players of tourism as they could provide the key elements for developing novel well-adjusted development strategies. Beyond these regards which expose the hard times and unique problem faced by tourism nowadays, the present paper takes into consideration an issue of no less: the local reaction to a global problem. The literature that goes into details on the actions taken by the public managers during pandemic, highlights the reaction phases to the crisis assembled into a general available model, namely the RISE model (resilience, intention, support) which is presented by Maher et al. (2020). The results of this model show that local administrations take innovative and strategic measures to fight the virus, even though COVID-19 exposes certain professional categories to social inequalities which are worsening as the virus is spreading.

\section{MATERIALS AND METHODS}

The decision to be in the business of tourism during and post-pandemic times is found, as we believe, in an interpretation paradigm. The reason behind this statement is the fact that tourism is a segment of activity where the perception on the space running the tourist activities is essential (Huete-Alcocer and Ruiz, 2019; Leung et al., 2013). Between April, 01, 2020 and May, 13, 2020, Suceava city and its neighbouring area ( 8 communes) were declared red zones (total quarantine) as measures taken for limiting the spreading of Sars-COV-2 virus. The city was the most affected one by the pandemic in Romania during the period mentioned earlier. Two months later, after the quarantine was lifted in the region, the public administration and tourism entrepreneurs were facing an attitude of uncertainty about the entire tourist region of Bukovina.

The starting point of the epistemological approach embraced by the present research relies on the fact that this pandemic has deeply affected the system of human, informal, and institutional relations on which tourism generally relies. The changes caused by the sanitary context, boosted by the role played by mass media on informing the public, and by the uncertainty of the time-horizon for making pertinent forecasts, have generated shock waves for each and every player engaged in tourism. This makes the new tourism reality far too complex to be merely described by a set of quantitative generalizations (Saunders et al., 2015; Piore, 2006). Whether we are talking about tourist, an administrator of a hosting facility, or local administration, each of these actors has their own view and understanding of the current situation. Under the circumstances, the data were collected by employing a mixed methodology, using both the qualitative and quantitative research (Creswell, 2007). Even though a mixed approach of methods has been used in this paper, the qualitative role had the leading part. We believe that its application is recommended for the phenomenon under analysis (Lee et al., 2013). The quantitative method has been used for classifying and measuring the impact of mass media on the tourist options of visiting a prestigious tourist destination which was identified with a region heavily affected by the pandemic. On the other hand, the qualitative method has been employed for getting information on the involvement degree of the local public administration in managing the crisis triggered by the pandemic, in supporting the tourism entrepreneurs, and in finding solutions for rebooting the local tourist activity (Matei, 2013). The first type of analysis is focused on tourists and has required a quantitative approach. Further, as a research tool, a questionnaire addressing potential tourists (Luo and Zhong, 2015) was applied online, which provided specific data and correlations on the tourist behaviour induced by the sanitary and mobility conditions imposed by the pandemic and, also helped outline the profile of the tourist who has chosen Bukovina as tourist destination this year. The questionnaire was distributed online between June 8 and June 30, 2020 and made use of the social media channels of promotion. Finally, 189 answers were validated, and, among these, 156 replies were given by persons who included Bukovina within their possible holiday destinations at the date of entry. The results obtained have been processed by using SPSS software to highlight the influence of different variables (age, residence, previous tourist experience etc.), and to outline the tourist profile during pandemic going to a destination whose image was profoundly affected at that time.

The qualitative approach of the present study is based on 11 interviews focused on the view of the persons questioned about tourist activities and evolution of tourism in Bukovina during and post-pandemic. The following have been interviewed: persons of the local public administration (a total of 4 persons), administrators/ owners of tourist facilities (5), and tourism agencies (2). The analysis started from the assumption that the tourism phenomenon is at a reboot point where it is vital to understand both the institutional and private mechanisms which need to be primed within a rational governance in order to achieve the resilience of a key economic sector of Bukovina region.

Although some researchers regard interviews as insufficient to reach objective conclusions (Dass and McDermott, 2020; Krippendorff, 2004), the published literature records different opinions as well, opinions which see interviews as useful instruments since they can catch the views of the subjects on a particular phenomenon and thus, provide depth to the quantitative researches (De Las Heras et al., 2020, Bryman, 2012; Qu and Dumay, 2011). In view of the present study, we have considered that, in an open discussion, the interviews have shaped the image of a different governance from the before-pandemic period, engaged into the necessity imposed by the current context.

\section{RESULTS AND DISCUSSION}

The sanitary crisis which started in early March at the same time in most European countries has created an unprecedented situation for the public institutions from each country affected by the pandemic. In the case of Romania, a survey run by the National Institute of Statistics (INS a, 2020), estimated that $95.4 \%$ of the economic agents included in the statistical research and which could assess the evolution of their activity volume, stipulated in April 2020 a shrinking of activity by more than $25 \%$ or even shutdown. By May 2020 , the arrivals registered by the hosting units dropped by $96.9 \%$ as compared to the data from the previous year recorded in May 2019 . According to the National Institute of Statistics, these data capture the impact of the COVID-19 crisis and of the measures taken by the authorities as result of enforcing the state of emergency on the $16^{\text {th }}$ of March 2020 and of the state of alert on $17^{\text {th }}$ of May 2020. Suceava County has registered for 
several months (March-July 2020) the most numerous cases of infections with the new coronavirus in Romania. The crisis from Suceava has started after mid-March when a major outbreak developed at Sf. Ioan cel Nou County Hospital, and, represented the beginning of the COVID-19 crisis in Romania. At the time when reporting the number of cases started at county level (April 2, 2020), in Suceava County there have been already registered over 700 cases, and 3 days later there were over 1000 cases, a number which most Romanian counties have not reached three months since the pandemic started. This negative aspect has determined the association of Suceava County with phrases such as "Lombardia of Romania" or "The Wild North" which had devastating effects on the image of the county and, also on the tourism sector. The quarantine of Suceava municipality and its neighbouring communes for one month and a half (April 1- May 13, 2020) has only put an emphasis on the negative image and resulted in building a negative climate about the chances of coming back to the normality, namely to travel under normal circumstances to Bukovina this summer. The image of the tourist destination is a concept including the sum of all beliefs, ideas, and perceptions a tourist shares about a tourist destination (Baloğlu and McCleary, 1999), and plays an essential part in the configuration of tourist preferences and opinions when choosing a holiday (Lin et al., 2007). In this context, the analysis of the perception felt by potential tourists about Bukovina, the identification of changes in tourist behaviour induced by the curre nt circumstances and those elements which give nuance to these changes, is a necessary approach for adjusting the tourist offer to the new requirements.

\section{The Perception of Tourists about Bukovina as Tourist Destination}

It is important to highlight the fact that most respondents $(86 \%)$ have holiday plans for this year, but most of them will choose a destination in Romania. Accordingly, a third of the respondents stated that they changed their holiday plan under the current circumstances, while a quarter said that they cancelled their initial plans. However, more than half of the respondents (67\%) said that they had not booked anything at the time, which shows the presence of uncertainty or a certain degree of wariness in taking decisions about this year holiday. These aspects have a definite negative impact on the tourism entrepreneurs who cannot anticipate how their tourist season will look like and need to take into consideration last-minute changes caused by the pandemic context and measures adopted. This aspect is also confirmed by the entrepreneurs from Vatra Dornei who did not have a clear picture of how their tourist season could look like in June 2020: "So, we are waiting at the time being, along with our clients, to see what the future has in store for us" (Valentina, tourism entrepreneur, Silva hotel, Vatra Dornei resort); "Until the government establishes what you can and cannot do, people are waiting and phones are not ringing. We are waiting the new regulations from the government. At the time, everything is unclear" (Mihaela, Neagra Șarului). It is still encouraging the fact that over $80 \%$ of the respondents who initially stated that Bukovina was a possible holiday destination, have not excluded it (yet) - this percentage also includes those people who stated that they did not take a firm decision. ("What has been booked from now on it has not been cancelled", Valentina C., tourism entrepreneur, Vatra Dornei resort). Most of the respondents, who declared that they excluded Bukovina from the holiday plans, belong to the category of those who wanted, most likely, to spend their holiday in the region during July-August 2020, which shows, at least, a mid-term effect of the crisis on the tourism in Bukovina and just a momentary impact, how, for instance, it happened in the case of the Easter reservations. The impact of the image created around Suceava County as a result of the sanitary crisis from March-April 2020, can be also observed in the analysis of the fears voiced by respondents to justify excluding Bukovina from the possible tourist destinations of this year. As was to be expected, the most frequently invoked fear by the potential tourists is not related to the tourist services from Bukovina (fear of getting infected in the hosting facilities and/ or public alimentation), but fear of the sanitary services provided by the county hospital in the event they may need them. Almost half of the respondents (42\%) who stated they excluded Bukovina from their holiday plans have given as main reason the fear of appealing to the medical services from the county of Suceava and this fear increases with age (Figure 1).

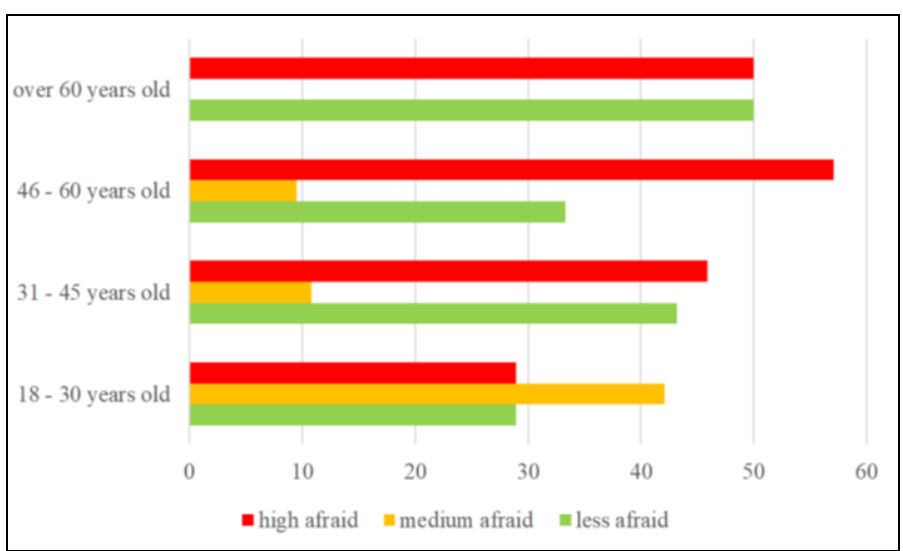

Figure 1. Did you exclude Bukovina as tourist destination because you were afraid of appealing to the medical services from the county of Suceava?
Once again, it is proven the interdependence between the image components of a territory as well as the sensibility of the tourism domain to all regional elements supporting its functions. If, in the case of other worries (getting infected in the hosting facility, in the public alimentation unit or anywhere in the area) which are related to what Bukovina has to offer as tourist destination, the more detailed knowledge of this space (acquired through a larger number of previous visits in the area) was reflected by a smaller percentage of the persons who invoked these reasons (fear to appeal to medical services and of a possible quarantining of the region), and this factor had no importance whatsoever. In the behaviour economy it is explained the impact of uncertainty (for instance, fear) on the tourist behaviour through the fact that, under such circumstances, the individuals choose to answer cautiously to the unknown (Mian and Sufi, 2010; Parker et al., 2013). For that matter, the most fearful of the respondents proved to be those from the neighbouring counties of Suceava, probably due to the direct access to more detailed information on the situation from Suceava County.

\section{Changes of the Tourist Behaviour during Pandemic}

In what concerns the specific features of the demand imposed by the current circumstances, they are also differentiated according to more variables and generally reflect the uncertainty generated by the pandemic context.

2.1. Type of Accessed Tourism

Most respondents (43\%) have stated that they are interested in the active and adventure tourism, which involves outdoor activities and relies on nature as natural resource. The cultural tourism, which is often associated with the idea of Bukovina as tourist de stination, appears as a third option for those who did not take out this destination from their traveling plans, while the balneotherapeutic tourism (Vatra Dornei resort, Cacica saline) is found on the fourth position, at a great distance from the rest of the options. Obviously, the options concerning the types of tourism are differentiated in accordance with age (those between 18 and 30 years old, namely $62.7 \%$ prefer the active and adventure tourism unlike those ranging between 46 and 60, merely 25\%), and origin of tourists (among the tourists who chose Bukovina this year, $55.6 \%$ showed their preference for an active tourism) (Figure 2).

2.2. Length of Stay and Group Size

Over $85 \%$ of the respondents have declared that they will travel by their personal car, while the other means of transportation have secondary positions. Quite interesting is the fact that in the case of foreign travellers the percentage of those who have chosen their own car goes higher than $75 \%$. Further, it is obvious the preference for going on trips in small groups of maximum 4 people (over $75 \%$ ). A proof of 
the fact that this relative small group can be interpreted as an adjustment to the current conditions imposed by the pandemic is given by the much higher percentage (89.9\%) of those who fit into this category out of the total of persons who stated that their main concern about traveling to Bukovina is related to the quality of medical services provided by the county hospital of Suceava.

The length of the stay appears to respond to the current restrictions, in the context when nearly half of the respondents declared that they are interested in a maximum 2-night stay in Bukovina (Figure 3). This feature is also shared with the respondents whose place of residence is located in far more distant county and have chosen, a percentage of $77.8 \%$, for a stay of maximum 5 nights.

2.3. Changes in Choosing the Hosting Units

Another aspect analysed through the questionnaire applied is directly linked to the structure of the hosting unit preferred by the tourists who did not exclude Bukovina from their holiday plans (Table 1). Most of them stated that they had chosen or intend to choose a rural locality in Bukovina, and the analysis of these destinations mentioned by tourists indicates well-known places, such as: Putna, Moldovița, Sucevița, and Cacica, along with occasional mountain destinations (Călimani, Rarău), as well as long-established balneotherapeutic resorts, namely Vatra Dornei and Gura Humorului. Regardless of the type of location chosen by the respondents (balneotherapeutic resort, rural locality, urban locality), the preferred structure of hosting unit was quite the same, more precisely a small guesthouse which, once again, shows an adjustment to the current circumstances. Additionally, in this case, the age factor makes certain differences as the youth (18 - 30 years old) are more willing to try other types of accommodation (although they prefer the small hosting structures), while the elderly (over 60 years old) have indicated the small guesthouses without exceptions (100\%).Another interesting matter is that the small guesthouse structures have been chosen by most respondents who preferred an urban locality in Bukovina. The preferred structure of accommodation is correlated with the length of stay, namely those willing to spend more time in Bukovina (5-7 days) are more inclined to choose a small accommodation structure (over 80\%).

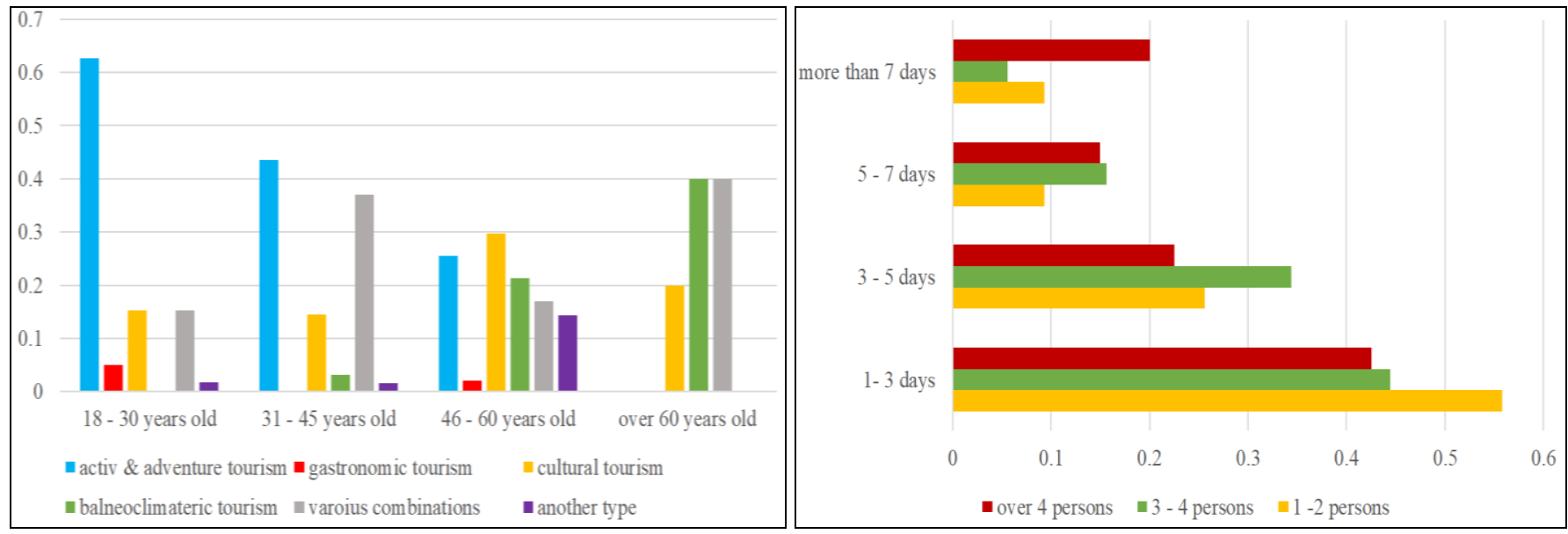

Figure 2. What kind of tourism most appeals to you in Bukovina?

Figure 3. What is the planned stay in Bukovina?

Table 1. Changes in Choosing the Hosting Units

\begin{tabular}{|c|c|c|c|c|c|c|}
\hline \multirow{2}{*}{\multicolumn{2}{|c|}{ If you choose to go to a rural settlement, what kind of accommodation do you prefer? }} & \multicolumn{4}{|c|}{ The duration of the trip } & \multirow{2}{*}{ Total } \\
\hline & & 1-3 days & $3-5$ days & 5-7 days & More than 7 days & \\
\hline \multirow{2}{*}{$\begin{array}{l}\text { Small } \\
\text { hotel }\end{array}$} & $\%$ within If you choose to go to a rural settlement, what kind of accommodation do you prefer? & $55.9 \%$ & $26.5 \%$ & $8.8 \%$ & $8.8 \%$ & $100 \%$ \\
\hline & $\%$ within The duration of the trip & $27.1 \%$ & $20 \%$ & $16.7 \%$ & $25 \%$ & $23.4 \%$ \\
\hline \multirow{2}{*}{$\begin{array}{l}\text { Big } \\
\text { hotel }\end{array}$} & $\%$ within If you choose to go to a rural settlement, what kind of accommodation do you prefer? & $60 \%$ & $20 \%$ & $0 \%$ & $20 \%$ & $100 \%$ \\
\hline & $\%$ within The duration of the trip & $4.3 \%$ & $2.2 \%$ & $0 \%$ & $8.3 \%$ & $3.4 \%$ \\
\hline \multirow{2}{*}{$\begin{array}{l}\text { Small } \\
\text { Pension }\end{array}$} & $\%$ within If you choose to go to a rural settlement, what kind of accommodation do you prefer? & $46.6 \%$ & $34.2 \%$ & $16.4 \%$ & $2.7 \%$ & $100 \%$ \\
\hline & $\%$ within The duration of the trip & $48.6 \%$ & $55.6 \%$ & $66.7 \%$ & $16.7 \%$ & $50.3 \%$ \\
\hline \multirow{2}{*}{\begin{tabular}{|l|} 
Large \\
Pension
\end{tabular}} & $\%$ within If you choose to go to a rural settlement, what kind of accommodation do you prefer? & $25 \%$ & $50 \%$ & $0 \%$ & $25 \%$ & $100 \%$ \\
\hline & $\%$ within The duration of the trip & $4.3 \%$ & $13.3 \%$ & $0 \%$ & $25 \%$ & $8.3 \%$ \\
\hline \multirow{2}{*}{$\begin{array}{l}\text { Other } \\
\text { Option }\end{array}$} & $\%$ within If you choose to go to a rural settlement, what kind of accommodation do you prefer? & $52.4 \%$ & $19 \%$ & $14.3 \%$ & $14.3 \%$ & $100 \%$ \\
\hline & $\%$ within The duration of the trip & $15.7 \%$ & $8.9 \%$ & $16.7 \%$ & $25 \%$ & $14.5 \%$ \\
\hline \multirow{2}{*}{ Total } & $\%$ within If you choose to go to a rural settlement, what kind of accommodation do you prefer? & $48.3 \%$ & $31 \%$ & $12.4 \%$ & $8.3 \%$ & $100 \%$ \\
\hline & $\%$ within The duration of the trip & $100 \%$ & $100 \%$ & $100 \%$ & $100 \%$ & $100 \%$ \\
\hline
\end{tabular}

\section{Partial Conclusions supported by the Qualitative Analysis}

The analysis on the specific features of the tourist demand under the current circumstances imposed by the sanitary crisis ou tlines a few aspects that are worth considering by the tourism players in Bukovina, at least in the case of the present tourist season. Firstly, a better communication about the medical crisis Suceava County went through, where it should be dissociated the image of tourist Bukovina from that of the outbreak generated by in the county hospital of Suceava - the city of Suceava and the periurban area (and which can be done through a constant detailed informing on the COVID-19 crisis, data supplied by the county hospital and constant reporting of the sanitary situation at a micro-territorial level) would have a positive effect on those who have not yet decided on spending their holiday in Bukovina and, also on those who did not make any holiday plans. Besides, there have been already taken some actions to remedy this aspect. Both public players who communicated data at the level of territorial-administrative unit, but did not provide sufficient continuity in doing that, and tourism entrepreneurs have involved in this endeavour to restore the image of Bukovina, as it can be observed in the interviews taken.

"But, to be sure, from now on we shall call the tourists who made reservations and see what they think about it. We have been keeping in touch with the clients, mostly by phone. They called us, and we called them too. They called to ask how things are here, if we have opened and under what conditions, while we called to check the reservations for the coming period." Valentina, C., Silva Hotel, Vatra Dornei

"We have also got in touch with our clients on the social media, but mostly by phone." Mihaela, I., agritourism guesthouse, Neagra Şarului.

Secondly, Bukovina should place its bets, at least in this early stage, on its natural resources, and the entrepreneurs could suggest tourist products for outdoor activities in less known or accessible locations. Last, but not least, the actors involved in the touris $\mathrm{m}$ development of Bukovina should make the best use of its particular features which define the accommodation units and are insufficiently promoted. 
"After the restriction period comes to an end, I believe that the tourism will relaunch because Bukovina has numerous small guesthouses, partially isolated and people are looking for that. There are many guesthouses of ten seats, as it was built at a certain time, where two families which are closed, related, and trust one another could stay together." Valentina, C., Silva Hotel, Vatra Dornei

"I believe that the small-scale tourism will do well, in other words we hope that the mountain tourism will do ok here, at least in this area. It would help us a lot if there were a differentiated promotion campaign between Suceava and Bazinul Dornelor, which is a very safe zone with many reliable agritourism guesthouses." Mihaela, I., agritourism guesthouse, Neagra Şarului

Interviewing the experts is one of the most engaged methods of the qualitative technique. In the second part of the study, we have chosen to use the interviews to allow the detailed collection of the views shared by several members of the local public administration regarding the institutional mechanisms supporting the tourism industry in Bukovina. All the interviews were conducted by phone during May 20 and June 20 , 2020. At the level of the county council of Suceava, there are department structures meant to provide development strategies and solutions for the issues related to the tourism within the county (The Tourism Office and the National Centre for Tourist Information and Promotion). Most projects of tourist promotion addressing Bukovina as tourist destination fall within the scope of county initiative, financing, and promotion, as it is probably one of the most active county structures dealing with big cultural events. Smart travel Bukovina, Green Pilgrimage, The Hora of Bukovina, The Easter in Bukovina, Medieval Art Festival, Pilgrim in Bukovina, Bukovina Rock Castle, Christmas in Bukovina, The Mountain Festival, Made in Bukovina Autumn Fair, etc. are tourist activities and registered trademarks of Suceava County Council which have brought dynamism to the tourism across the entire territory of Bukovina. At the level of territorial-administrative units, most of them have strategies for tourist development where the emphasis is put on unlocking the ethno-folkloric potential or/ and on initiatives related to the outdoor and winter tourism. For instance, in Gura Humorului town, a project financed by the World Bank is the financial plan on short and medium period of the town (2005). For 15 years now, tourism has been identified as the main recovery resource of the town on the threshold of disaster after shutting down the mines and light-industry factories. In the paragraph below it is rendered the vision of the then mayor of Gura Humorului town:

"There are resources. There is potential. There is room. Tourism must be seen as economic development, not just as facilities for the town's people. They can come to the public swimming pool too, but we need more facilities. We need to come with money from other part and develop the town"

In this context, the following research questions have been asked:

1. By declaring Suceava city a red zone did it affect the perception of the tourists about Bukovina as tourist destination?

2. Which resources and strategies did the local administrations from Bukovina mobilize during the crisis for the resilience of the tourism sector?

3. How do you see the future of tourism in the post-pandemic Bukovina?

4. Is there a positive impact of this period?

The questions above have provided the basis of the interviews for the categories of persons interviewed. The answers, more or less nuanced, make the basis of the qualitative research.

1. By declaring Suceava city a red zone did it affect the perception of the tourists about Bukovina as tourist destination?

In the tourism area of Bukovina, the municipality of Suceava was the most affected zone by the SARS-CoV-2 pandemic. Even if the municipality does not fall into the category of the main tourist attractions of Bukovina, the effects upon the perception of sanitary safety have reflected on the entire tourist region through two main features:

-The reality of the sanitary crisis which lead to radical measures of quarantining the metropolitan area and occupied all the efforts of the administration during quarantine with a direct focus on the county hospital and the pandemic state of emergency:

"The county administration was absent on the public market for a while, to say so... All the efforts were focused, for several months, on the hospital and sanitary crisis. No one was engaged in other activities, regardless of their type." (Emil, U. — manager of Bukovina Museum).

-The role played by the mass media in exacerbating this deficit of image, difficult to surpass for a good period, in spite of the fact it made reference to a particular situation. "Even if this (the quarantine, in the context) was a reality, the news exacerbated the situation to the point that they created a Chernobyl like perception for the entire country. I have colleagues from other parts of the country who are now waiting to see me because they imagine I have become some sort of mutant since the quarantine." (Emil, U. — manager of Bukovina Museum).

"Definitely! The outbreak from Suceava (the municipality of Suceava) has complicated things and made tourists become more susceptible about Bukovina!" (Mihaela, I. - owner of an agritourism guesthouse in Neagra Sarului).

"We clearly have an image problem. I hope that things will come back to normal. But, [...] what do I know? The county council has not taken sufficient measures to counter fight the PR coup suffered.” (Laurențiu, B. - manager of a tourism agency) .

The solutions for rebuilding the media image are seen at the level of county administration only. Even if, during all this period of sanitary crisis the prefect's office was mainly focused on applying the emergency ordinances on limiting the spread of COVID-19 virus, the fact that the effects of the pandemic upon the tourism and economic activities within the county were entirely neglected, proves a poor response capacity in times of crisis of the central authorities.

2. Which resources and strategies did the local administrations from Bukovina mobilize during the crisis for the resilience of the tourism sector?

Among the answers received at this question, we have come across two types of governance: the first category includes those administrations waiting for governmental solutions to the crisis, which are then applied to the actors from the local tourism.

"Something was granted (from the government, in this context) for the SMEs, at least in intention, but from what I have seen, money hardly come for companies." (Petre, A. - adviser at the Town hall of Vatra Dornei).

"Practically, I was helped by the government." (Valentina, C. - manager of Hotel Silva, Vatra Dornei resort).

We are mainly speaking about reducing taxes and duties and postponing their payment, or counselling for temporary unemployment or postponing the payment of bank loans. The second category includes a relatively small number of town halls which implement a governance where the public management is approached from the perspective of an entrepreneurship where the town hall is the main shareholder. In this case, the measures are considered and taken in view of counter fighting the projected deficit of the current-year budget and of supporting and continuing the ongoing projects.

"I have to find solutions within the current legislative framework, so I can rely as little as possible on the central administration... Anything that comes from the government is a bonus." (Marius, U. - mayor of Gura Humorului town)

"It takes a manager in the public local administration, who has the vision to make a general puzzle. Who knows where is the place of each piece." (Marius, U. - mayor of Gura Humorului town).

The promotion of artistic, craft activities is mainly suspended in its traditional form as these types of events can generally happen in the virtual space, online by the decision of the local counties (The Trout Festival, the Festival of the Painted Eggs, the Rafting Week Ciocănești, etc.) by those from the Suceava municipality (Castle Rock and the Medieval Art Festival). The sums projected for promoting Bukovina as tourist destination through festival tourism have been reoriented towards the hospital and supporting the sanitary crisis within the county. To support the economic activities within Gura Humorului town, the town hall supplemented the support given to the 
entrepreneurs by a series of measures, such as: reducing taxes and duties by $50 \%$, cancelling the penalties for those who had accumulated debts from previous years, reducing rents for the spaces leased, cancelling the concession of some parking lots on public domain, reducing taxes by $25 \%$ in the farmers 'market. A suggested solution for restoring the tourist flows in the area is a support granted indirectly to the tourism operators, namely per tourist. It is important to give these financial incentives to the tourists and not operators, since if the latter get the money, the impact on restoring the image of Bukovina will be minimum or quite non-existing. The tourism operators are not interested in orienting tourists to Bukovina, therefore, the tourists need to be tempted to overcome the blockage of opting for Bukovina.

"If you go on holiday to Bukovina, you have some benefits... (reductions, extra services, etc). Personally, I see things this way: I, a tourist who comes to an X guesthouse in Bukovina, regardless of the fact that I use vouchers or my own money, I have a less expensive accommodation, let's say by $20 \%$. Those $20 \%$ are discounted to the guesthouse by the government. But they are discounted per tourist. If I give 5000 Euros to a guesthouse because it was affected by the pandemic, I do not solve anything on medium and long-term. The operators spend those 5000 Euros, and the tourists do not come to Bukovina". (Emil, U. - manager of Bukovina Museum)

In the same spirit, the mayor of Gura Humorului town sees a direct involvement of the local administrations, partners in the project Bukovina Resort granted as an accommodation package including various services (attractive prices for railway transportation, ski cable cars, etc.) for the tourists who choose the offers of Bukovina Resort.

"This is the interest: to move tourists in the area. A restaurant in every car of the train. How do we do it? Not we. It is necessary to lease this service. For this area only. The tickets are cheaper. All operators would be interested. That's why it is necessary to have private entrepreneurs in this project. The private area needs to be captured. The guesthouses should have tourist information and mobility facilities for the tourists checked in. One unitary matter: not all the ski slopes are managed by authorities. Here is the key element of development. The partnership between the public and private domain." (Marius, U. - mayor of Gura Humorului town)

The local administration is regarded, inside, as a management invested with a specific governance tied to the tourism development, having, thus two perspectives: one is identified with the current one, of association at a macro level within the region as Bukovina Resort, while the other one is local, taking the shape of associative structures which can become spoke and interest delegates of the tourism operators in the area.

"A syndicate from where I can get information. ... The Association for the Tourism Development of Gura Humorului.... who knows better than the tourism operator what exactly wants the tourist? " (Marius, U. - mayor of Gura Humorului town)

The pandemic and the period of freezing the tourism activities has seriously affected the budget of the town halls in Bukovina. The level of collecting taxes and duties has been significantly reduced by comparison to the previous years, by nearly $40 \%$. Under the circumstances, to continue the current investments, among which European projects, the administrations have been forced to resort to bank loans.

3. How do you see the future of tourism in the post-pandemic Bukovina?

The question is tricky since the tourism sector is dominated by total uncertainty when it comes to estimate the future evolution of pandemic and coming back to normal conditions of running the tourism activities. The relaunching of the tourism activity pres ents two sets of actions: the former is related to rebuilding the damaged image of Bukovina associated with a severely affected zone by the pandemic. The latter implies continuing the investment projects in tourist facilities (for instance, the Cultural Mall from Gura Humorului, theme park, aqua land, the castle of the hobbits, etc.), supported by a series of concrete, customized actions through the initiative of some media personalities who could come to Bukovina and be part in various artistic and cultural events of high visibility at national level.

"I have initiated an event ... a series of meetings with the music lovers, where very well-known stars of the Romanian music will be present: Andra, Smiley, Scărlătescu, Țăndărică, from various music genres. The key point of these actions is the fact that these celebrities will come accompanied by their dedicated press, mainly the central press. I see things this way: the celebrity comes, meets with the public (obviously, the number of people will be limited) in a live broadcast of a local television, after the celebrity goes and checks in a guesthouse in the county and says that the area is safe." (Emil, U. - manager of Bukovina Museum)

The opinion of the persons interviewed is that the tourism in Bukovina relies on the unified actions of all actors involved. It engages local authorities, operators, and central authorities. Each has its well-defined part, even if not all the entities can have a similar reaction.

"The main power of recovery relies on the operators, I believe. Whether we are talking about guesthouses, restaurants, hotels, along with museums and monasteries which I consider operators too. Secondly, a particularly important role belongs to the local community." (Emil, U. - manager of Bukovina Museum). The local administrations are heavily engaged, under the office of county council, in major initiatives for attracting funding necessary for the development of the tourism infrastructure. One of these initiatives is to create a pole of tourism development for Bukovina, which should take the form of an association agreement between the county council and Gura Humorului, Câmpulung, Vatra Dornei resorts, and Cacica saline within the context of building the tourist resort of Bukovina. The advantage of such an association for all the entities involved, would reside in the extended governance over the access infrastructure, with a special accent on the existing railway and its partial transformation into a tourist transport network with related se rvices and thus, benefits for every locality on this axis. If, until now, this initiative has been somehow divergent, the current context has created the necessity of mobilization for a common goal (using the existing accommodation capacity by reinforcing the pre-existing tourist infrastructure and raising the accessibility of the railway to the mountain, woods, mineral waters, UNESCO monasteries, ski-slopes, gastronomic locations).

"Everybody wants highways, nobody uses the train. ... However, until you make a highway, the problem must be solved. The train becomes cost-effective if the railway is subsidized, after a clear, practical circuit is created. There are European funds which we do not wait from the office of ministry." (Marius, U. - mayor of Gura Humorului town)

4. Is there a positive impact of this period?

The final methodological batch of this paper has taken into consideration the extent to which the local public administration regarded the numerous malfunctions generated by the measures meant to limit the spread of the pandemic, through the perspective of opportunities. Below there are mentioned some of these:

-The social impact through raising the awareness on the necessity of maintaining the tour operators in tourism;

-If the situation is correctly handled in terms of economics and pandemic, the county of Suceava can become an example of good practice in times of crisis;

-The emergence of new forms of tourism in areas where they have not been present before, such active, outdoor tourism;

-The revival of the home tourism and small structures of accommodation, which are isolated and more adjusted to the new demands of sanitary safety;

-The rural space is at gain here. The ecotourist destination will most likely develop.

\section{CONCLUSION}

The same as every domain of human activity, the impact of pandemic upon tourism in Bukovina will be fairly assessed once all restrictions are lifted and everything returns to the normal activities. Now, the model of action is the day by day approach due to the degree 
of uncertainty and low predictability. As it is about a sector where the human interaction is essential, we can estimate that, in the case of Bukovina, the utilization degree of the tourist capacity will be initially reduced by $50 \%$, which will impact on the income of the tourism entrepreneurs, at least in the same percentage. If we consider the fact that tourism is an important element of the local budgets managed by local administrations, the recovery of small enterprises operating in tourism could be also primed by public-private partnerships.

On short and medium- term, regardless of the major changes undergone by tourist activities in this area, there are visible two types of scenarios: the former is an optimistic one, which promotes the coming back to the normal parameters within one year once the state of emergency was lifted, and the latter, which is more pessimistic and says that the tourism will be restored to the previous parameters no sooner than 18 months since the pandemic ended. In both situations, the tourism will be generally maintained through an acti ve type of tourism (agritourism, trips, ecotourism, cyclo-tourism, hippo tourism) which uses the natural potential of Bukovina. In the near future, one attraction will become the tourism oriented towards the natural reservations (The Woods of Slătioara have become UNESCO site, Călimani National Park, Todirescu-Rarău Reservation, etc.). The most affected will be the balneo-therapeutic tourism and festival tourism as well, which are quite difficult to estimate when they can safely come back in the circuit. Although the business tourism is another affected sector, we believe that it will soon recover due to the potential of the exceptional entrepreneurship found in Bukovina.

The first forms of tourism which are starting to be seen are the family or individual tourism. The people will look for destinations less crowded and, from this point of view, Bukovina is quite renowned. These types of tourism will be also supported by the holida y vouchers whose validity has been extended, and by the necessity of reviving the internal tourism.

What will change in the tourism of Bukovina, in our opinion, is the extent of involvement of the local and county administration in the social and economic life of the communities managed. Against a general identical background, each local administration had a different type of resilient behaviour. A possible gain of this trying period for the whole region is raising awareness on the necessity of association between the actors of the tourist market, both at local and county level.

\section{REFERENCES}

Baloğlu, Ş., \& McCleary, K.W. (1999). A model of destination image formation. Annals of Tourism Research. 26, 868-897. https://doi.org/10.1016/S01607383(99)00030-4

Bryman, A. (2012). Social Research Methods, Oxford University Press, New York, 15-17.

Chebli, A., \& Said, B.F. (2020). The impact of Covid-19 on tourist consumption behaviour: a perspective article. Journal of Tourism Management Research, 7(2), 196-207. https://10.18488/journal.31.2020.72.196.207

Creswell, J. (2007). Educational Research: Planning, Conducting, and Evaluating Quantitative and Qualitative Research. Pearson Education, New York, 3-4.

Dass, M., \& McDermott, H. (2020). Travel \& Tourism Global: Potential Impact of the Coronavirus. Tourism Economics, Philadelphia, 1-25.

De Las Heras-Pedrosa, C., Millan-Celis, P., Iglesias-Sánchez, I. \& Jambrino-Maldonado, C. (2020). Importance of Social Media in the Image Formation of Tourist Destinations from the Stakeholders'Perspective. Sustainability, 12(4092), 1-27. https://doi.org/10.3390/su12104092

Gössling, S., Scott, D., \& Hall, C.M. (2020). Pandemics, tourism and global change: a rapid assessment of COVID-19. Journal of Sustainable Tourism, 1-21. https://doi.org/10.1080/09669582.2020.1758708

Higgins-Desbiolles, F. (2020). Socialising tourism for social and ecological justice after COVID-19. Tourism Geographies, 22(3), 1-15.

Huete-Alcocer, N., \& Ruiz, V.R.L. (2019). The role of destination image in tourist satisfaction: The case of a heritage site. Economic Research-Ekonomska Istraživanja, 1-18. https://doi.org/10.1080/1331677X.2019.1654399

Krippendorff, K. (2004). Content Analysis: An Introduction to its Methodology. SAGE Publications, London.

Lee, B., Lee, C.K., \& Lee, J. (2013). Dynamic Nature of Destination Image and Influence of Tourist Overall Satisfaction on Image Modification. Journal of Travel Research, 53, 239-251. https://doi.org/10.1177/0047287513496466

Leung, D., Law, R., Van Hoof, H., \& Buhalis, D. (2013). Social Media in Tourism and Hospitality: A Literature Review. Journal of Travel \& Tourism Marketing, 30, 3-22. https://doi.org/10.1080/10548408.2013.750919

Lin, C.H., Morais, D.B., Kerstetter, D.L., \& Hou, J.S. (2007). Examining the Role of Cognitive and Affective Image in Predicting Choice Across Natural, Developed, and Theme-Park Destinations. Journal of Travel Research, 46, 183-194. https://doi.org/10.1177/0047287506304049

Luo, Q., \& Zhong, D. (2015). Using social network analysis to explain communication characteristics of travel-related electronic word-of-mouth on social networking sites. Tourism Management, 46, 274-282. https://doi.org/10.1016/j.tourman.2014.07.007

Maher, C., Hoang, T., \& Hindery, A. (2020). Fiscal Responses to COVID-19: Evidence from Local Governments and Nonprofits. Public Administration Review, 80(4), 644-650. https://doi.org/10.1111/puar.13238

Matei, D. (2013). Entrepreneurship in the romanian rural areas. Case study: Suceava county. Journal of Settlements and Spatial Planning, 2, $281-285$.

McKibbin, W., \& Fernando, R. (2020). The Global Macroeconomic Impacts of COVID-19: Seven Scenarios. Covid Economics, 10, $116-156$.

Mian, A., \& Sufi, A. (2010). The great recession: Lessons from microeconomic data. American Economic Review, 100(2), 51-56. http://www.aeaweb.org/ articles.php?doi=10.1257/aer.100.2.51

Muscalu, M.S. (coord.), Băleanu, D.N., Bodea, C.N., Fistung, D.F., Iștoc, E.M., Isaic-Maniu, A., \& Stancu, S. (2020). Impactul pandemiei Covid-19 asupra unor activități economice din domeniile serviciilor si întreprinderilor mici și mijlocii [Impact of the Covid-19 pandemic on economic activities in the fields of services and small and medium-sized enterprises'onomic in March and April 2020]. Institutul Naţional de Cercetări Economice „Costin C. Kirițescu”, [National Institute of Economic Research „Costin C. Kirițescu”], 1-45.

Novelli, M., Burgess, L. G., Jones, A., \& Ritchie, B.W. (2018). No Ebola... still doomed-The Ebola-induced tourism crisis. Annals of Tourism Research, 70, 76-87. https://doi.org/10.1016/j.annals.2018.03.006

Özdemir, A., \& Yildiz, S. (2020). How Covid-19 outbreak affects tourists' travel intentions? A case study in Turkey. Social Mentality and Researcher Thinkers Journal, 6(32), 1101-1113. http://dx.doi.org/10.31576/smryj.562

Parker, J.A., Soules, N.S., Johnson, D.S., \& McClelland, R. (2013). Consumer spending and the economic stimulus payments of 2008. American Economic Review, 103(6), 2530- 2553. https://doi.org/10.1257/aer.103.6.2530

Piore, M.J. (2006). Qualitative research: Does it fit in economics? European Management Review, 3, 17-2. https://doi.org/10.1057/palgrave.emr.1500053

Saunders, M.N.K., Lewis, P., \& Thornhill, A. (2019). Research Methods for Business Students. 7th ed., Pearson Education, New York, $1-741$.

Sigala, M. (2020). Tourism and COVID-19: Impacts and implications for advancing and resetting industry and research. Journal of Business Research, 117, 312 -321. https://doi.org/10.1016/j.jbusres.2020.06.015

Qu, S.Q., \& Dumay, J. (2011). The qualitative research interview, 2011. Qualitative Research in Accounting \& Management, 8, 238-264. https://doi.org/10. 1108/1176609111116207

Wachyuni, S.S., \& Kusumaningrum, D.A. (2020). The Effect of COVID-19 Pandemic: How are the Future Tourist Behavior? Journal of Education, Society and Behavioural Science, 33(4), 67-76. https://doi.org/10.9734/jesbs/2020/v33i430219

*** Institutul Național de Statistică al României [National Institute of Statistics in Romania] (a), (2020). Evaluarea impactului COVID - 19 asupra mediului economic în lunile martie și aprilie 2020 [Assessment of the impact of COFID - 19 on the economic environment in March and April 2020], 1-10.

*** Institutul Național de Statistică al României [National Institute of Statistics in Romania] (b) (2020). Cercetare experimentală: Evaluarea impactului COVID-19 asupra mediului economic în lunile martie și aprilie 2020 [Experimental research: Assessment of the impact of COVID-19 on the economic environment in March and April 2020], 1-10.

*** The World Tourism Organization (2020). Baromètre OMT du tourisme mondial mai 2020, Avec un accent particulier sur l'impact de la COVID-19 (Résumé), 1-25.

*** The World Tourism Organisation (2020). Covid-19: Putting people first, 1-45. 